wish to die. In suicidal attempts there is an implied intention to kill oneself and therefore an emergency compulsory order (Section 29, Mental Health Act, 1959) seems indicated, even in the absence of other psychological abnormalities.

The second problem is one of disposal. Suicide attempters ought not to be admitted directly to a mental hospital since their immediate needs are medical or surgical in nature. Some regional hospital boards emphasize this point. Mental hospitals have not the same facilities to deal with emergencies; besides their usually remote location implies the loss of valuable time, which in emergencies can make all the difference.

I believe that such patients, after being put on an emergency three-day order, ought to be detained in a general hospital. This procedure is in accordance with the abolition of " designated hospitals" for the treatment of mental illnesses of the Mental Health Act, 1959. After preliminary first aid and short observation in the general hospital the patient is seen by the psychiatrist and transferred to a mental hospital if necessary.

Though this procedure seems a logical one some general hospitals refuse admission of patients on a compulsory order. In view of the controversial nature of this topic, comments from the Ministry of Health may help to clarify this matter.-I am, etc.,

Storthes Hall Hospital, D. H. Ropschitz. Huddersfield, Yorks.

\section{Vitamin $\mathbf{C}$ and Gastroduodenal Disorders}

SIR,-We were interested to read the reports by Dr. J. M. Williamson and others (1 April 1967, p. 23), by Dr. M. M. Cohen and Miss Anne $M$. Duncan (2 December 1967 , p. 516), and the letter by Dr. I. W. Dymock and others (20 January, p. 179) on the estimation of leucocyte ascorbic acid levels in patients with malabsorption or gastroduodenal disorders. Using the method adopted by these authors, we have also found a marked depletion of ascorbic acid in subjects with duodenal ulcer. The mean leucocyte ascorbic acid level in 16 patients was $10.6 \mu$ g. $/ 10^{8}$ W.B.C. (S.D. \pm 4.9 ), while that in the controls was $22.1 \mu \mathrm{g} . / 10^{2}$ W.B.C. (S.D. \pm 6.4$)$.

We have attempted to assess if ascorbic acid deficiency was correlated with secretory capacity on maximal histamine stimulation. Low levels of leucocyte ascorbic acid were found both in subjects with hypersecretion and hyperchlorhydria, and in patients with normal secretory results. These findings suggest that depletion of vitamin $C$ in such disease is independent from the degree of gastric acid concentration. We have also studied ascorbic acid metabolism in three cases of diaphragmatic hernia, in four cases of ulcerative colitis, and in 12 cases of advanced liver cirrhosis, all of whom were known to have an intake of ascorbic acid of at least $30 \mathrm{mg} . /$ day. In the first two conditions the leucocyte ascorbic acid test showed a significantly lower level than in the control group; in patients with liver cirrhosis the mean buffy layer ascorbic acid level was $13.1 \mu \mathrm{g} . / 10^{*}$ W.B.C. (S.D. \pm 5.1 ).

From such preliminary findings it would appear that ascorbic acid deficiency is found also in states-for example, advanced liver cirrhosis, in which dysfunctions of gastrointestinal motility and absorption are often present. It is not yet clear if ascorbic acid is absorbed through the intestinal mucosa by diffusion or by active transport process, ${ }^{1}$ but it may be suggested that inadequate absorption of the vitamin in such conditions is the most important factor causing its deficiency. Reduction of the dietary intake or increased utilization of the vitamin can obviously concomitate, and in some cases they could play the prevalent pathogenetic role. -We are, etc.,

\section{Institute of Medical University of Milan, \\ Italy. \\ ROMaNo ValENTINI.}

\section{REFERENCES}

Spencer, R. P., Purdy, S., Hoeldtke, R., Bow, . M., and Markulis, M. A., Gastroenterology, 2 Stewart, J.' S., and Booth, C. C., Clin. Sci., 1964,
27, is.

\section{Cyclamates}

SIR,-Yqur leading article on "Cyclamates" (9 March, p. 594) contained the following statement: "Such evidence as existed suggested that toxicity of cyclohexylamine itself was low." This statement could be misleading. In fact the oral L.D.50 for cyclohexylamine in the rat had been shown to be in the region of $300 \mathrm{mg} . / \mathrm{kg}$. body weight. ${ }^{1}$ This contrasts with that for sodium cyclamate, which had been shown to be $6,000-12,000 \mathrm{mg} . / \mathrm{kg}$. body weight." Furthermore, cyclohexylamine had been shown to cause changes in the liver and kidneys of rats at a dosage level of $60 \mathrm{mg}$./ $\mathrm{kg}$. body weight. ${ }^{3}$ It is hoped that the further studies that have been requested will show that cyclohexylamine does not present any hazard to man at the levels that are likely to occur after consuming cyclamate-containing foods. However, it is idle to suggest that conversion of cyclamate to cyclohexylamine does not materially alter the potential hazard -I am, etc.

$$
\begin{aligned}
& \text { British Nutrition } \\
& \text { Foundation Ltd. }
\end{aligned}
$$$$
\text { London S.E.1. }
$$

Alastair Frazer.

\section{REFERENCES}

1 Flinn, F. B., Ind. Eng. Chem., 1937, 29, 1247. and Duescher, H. O., J. Amer, pharm. J. L.,

1951, 40, 1.
6, 22. B., Probl. Oncol. (N.Y.), 1958, 4, No.

\section{Royal Malady}

SIR,-The proponents of the theory that George III and others suffered from variegate porphyria have had a good run recently in your correspondence columns. May I try to sum up ? We seem to be divided still on two fundamental issues-namely, is variegate porphyria a really serious disease in its own right when not provoked by modern drugs, and is it sufficiently similar to acute intermittent porphyria to allow experience of the latter to be applied usefully to patients with the former? My position here is that only one clinician has really adequate and reliable knowledge of variegate porphyria as such, and he (Dr. G. Dean,
17 February, p. 443) has clearly stated that the case for the alleged royal malady is not proved. This was mainly on the grounds that variegate porphyria in the past was not a serious disease, but also from his knowledge of hundreds of living patients who are kept off certain drugs. The most I can allow is that in time, when we have in Great Britain collected sufficient cases of proved variegate porphyria to allow our having proper opinions of our own, it may be that we could find that our so-called variegate porphyria is not the same as the South African variety either genetically, biochemically, or clinically. Current findings make this seem rather unlikely, although in the world of biochemical genetics it is very common to find that an alleged single disease, for instance phenylketonuria, is later found to be more than one disease.

May I take a firm stand about the visible urinary changes ? I insist still that the urine in an acute attack of either form of porphyria is usually of normal colour when freshly passed. The essential and characteristic feature, not present in the descriptions of the royal malady, is the development of reddish or brownish coloration on standing. This still occurs even in those rarer cases when the urine is passed already slightly coloured. The reference quoted by Professor Rimington (24 February, p. 510) from Drs. Waldenström and Vahlquist is unfortunately incorrectly described. These authors state that if the urine is passed strongly acid the darkening on standing occurs more quickly than if alkaline. They did not state that acid urine is passed already coloured, nor that it does not then further darken on standing. Their colour plates of this phenomenon should, by the way, be inspected by those who may still feel that the colours in question bear any relation to what we usually call purple.

I am sorry my genetic thoughts have not got across to Professor A. Goldberg (24 February, p. 509), who somehow relates them to "mathematical pyrotechnics." May I try again with briefer family tree and leaving out all figures and horrible calculations ? What I am now trying to point out is that if, as Dr. Ida Macalpine and her colleagues suggested, the variegate porphyria gene passed directly down the royal line from Mary Queen of Scots to George IV - that is, through nine generations-then the gene must have had an uncanny knack, defying, I think, scientific explanation, for picking out the subjects in the direct line of succession : first son when available, otherwise whoever comes next according to the particular rules in this complicated game. Perhaps he will think again about the relation of these manmade laws of inheritance to those put forward by Mendel, bearing in mind the now generally accepted rules for the inheritance of an autosomal dominant gene. Till he has explained the alleged royal inheritance to me I will continue to tell the students here that the reassortment of genes before each conception is "just a blinking lottery" and that this occurs among royalty just as in the common herd.

My object in raising these matters originally was to tell historians that there is considerable doubt among some clinicians interested in the porphyrias about the story of the roya! malady. I was most distressed to note that one historian seemed to have swallowed the story hook, line, and sinker 